\title{
Measurement of Water Quality Parameters for Before and After Maintenance Service in Water Filter System
}

\author{
Nuraida Shaharudin ${ }^{1, *}$, Nurfarhana Suradi ${ }^{1}$, Nor Amani Filzah Mohd Kamil ${ }^{1}$ \\ ${ }^{1}$ Water and Environmental Engineering Department, Faculty of Civil \& Environmental Engineering \\ UniversitiTun Hussein Onn Malaysia, BatuPahat, Johor, Malaysia.
}

\begin{abstract}
An adequate supply of safe drinking water is one of major ways to obtain healthy life. Water filter system is one way to improve the water quality. However, to maintain the performance of the system, it need to undergo the maintenance service. This study evaluate the requirement of maintenance service in water filter system. Water quality was measured before and after maintenance service. Parameters measured were $\mathrm{pH}$, turbidity, residual chlorine, nitrate and heavy metals and these parameters were compared with National Drinking Water Quality Standards. Collection of data were involved three housing areas in Johor. The quality of drinking water from water filter system were analysed using $\mathrm{pH}$ meter, turbidity meter, DR6000 and Inductively Coupled Plasma-Mass Spectrometer. $\mathrm{pH}$ value was increased from $16.4 \%$ for before maintenance services to $30.7 \%$ for after maintenance service. Increment of removal percentage for turbidity, residual chlorine and nitrate after maintenance were $21.5,13.6$ and 26.7, respectively. This result shows that maintenance service enhance the performance of the system. However, less significant of maintenance service for enhance the removal of heavy metals which the increment of removal percentage in range 0.3 to 9.8 . Only aluminium shows percentage removal for after maintenance with $92.8 \%$ lower compared to before maintenance service with $95.5 \%$.
\end{abstract}

\section{Introduction}

Malaysians spend billions of ringgits each year on water filter system units that installed in their house. According to the survey National Consumer Water Quality January 1999, 38\% of resident use a water filter system at home which is increase by $10 \%$ since 1995 [1]. By comparing to nowadays, the number of user may be increase double or triple. It is shown that most Malaysian used water filter system to improve on their tap water in whole Malaysia. [2] was conducted a study to compare water quality from water filter system and user perception. Mostly respondents were not satisfied with the water supply to their homes. The respondents also think that the water could bring adverse impact to their health if no water filter system installed in their homes. Finding from the study was similar with

*Corresponding author: noramani@uthm.edu.my 
[3] which main problems with their tap water was colour, odour and taste. The study also reported that $85 \%$ of respondents used water filter system in their homes due to convenience and comfortable compare to boiling the water.

Some of the users rarely or do not conduct any maintenance service for their water filter system [2]. This is may be due to manufacturer only supply the water filter system to user without explaining the maintenance service that need to be conducted by user. User that had used the water filter system must carry out proper maintenance periodically as recommended by the supplier to ensure the quality and safety of the tap water. If no maintenance service was conducted, maybe other contaminants that flow into the system may increase the contaminant's concentration and effect the effluent water. [4] found that concentration of bacteria was 10,000 times higher in filtered water compare to ordinary tap water which may be due to growth or biofilm formation in the filter material. The filter material contains a mixture of ion exchange resins and silver impregnated activated carbon. From time to time, the filter maybe covered with contaminants and debris and affected the flow of water through the filter. When the water flow drastically reduced, the filter system may produce very high concentrations of contaminants.

Many studies were conducted to evaluate the performance of water filter system and these studies have shown high removal percentage [5-9]. [5] showed that reverse osmosis in water filter system removed total suspended solids and turbidity more than $99 \%$ and $98 \%$, respectively, by using electrocoagulation as a media filter. Study conducted by [6], showed that water filter system based on ultrafiltration removed of $97 \%, 95 \%$ and $99 \%$ of arsenic, organic matter and turbidity, respectively, by using trickling filter with biosand filter. Moreover, [7] shown that the percentage removal for lead, barium, nickel and copper were more than $80 \%$. The study use bench-top water filter and the media wasion exchange resin and Silverized granular activated charcoal. [8] shown the percentage removal for arsenic is $95 \%$ by using a ceramic filter as water filter system and the media is clay soil and rice bran. According to [9], the percentage removal for arsenic were $7.7-50 \%$ by using modified homemade filter and the media was crushed brick. Even though the percentage removals were high and shows the good performance of water filter system, the performance after long duration is not emphasize. In addition, the quality of water after maintenance service was never measure.

In this study, the effectiveness of maintenance service on water filter system was analyzed. Result from the analysis was compared with National Drinking Water Quality Standards to ascertain the effluent water safe for drinking. Parameters selected for this study were $\mathrm{pH}$, turbidity, chlorine, nitrate and heavy metals (arsenic, barium, cadmium, copper, chromium, ferum, lead, nickel, aluminium and selenium).

\section{Material and method}

This section consists of sampling areas and sampling handling and analysis of water quality parameters.

\subsection{Sampling areas and sampling handling}

Three housing areas were selected as site locations which are Taman Pura Kencana in Seri Gading, Kg. Melayu Majidee in Johor Bahru and Taman Perling in Johor Bahru. These selected housing areas can be categorized as terrace housing. These sampling areas were chosen due to the usage of similar water filter systems

Water sampling was carried out twice every two months of maintenance service in each site. Polyethylene bottles were used for collection of water samples which had been thoroughly washed and rinsed using distilled water to flush out any concealed pollutants. 
For each sampling area, three samples from outlet before maintenance service and three samples from outlet after maintenance service were collected. Unfiltered water samples were collected from a water tap on site. Water samples were kept in low temperature at $4^{\circ} \mathrm{C}$ in the dark before testing. The samples were analysed within 48 hours for $\mathrm{pH}$, turbidity, residual chlorine and nitrate. Meanwhile, for heavy metals the holding time for samples can be up to 6 months if properly preserved.

\subsection{Analysis of Water Quality Parameter}

Water samples collected from water filter system was tested at the Environmental Laboratory in Universiti Tun Hussein Onn Malaysia. $\mathrm{pH}$ was analysed by using $\mathrm{pH}$ meter onsite. Turbidity was tested by using turbidity meter. Residual chlorine and nitrate were analysed using UV-VIS spectrophotometer (DR6000) by using Method 8021 and Method 10206, respectively. Heavy metals, i.e., arsenic, barium, cadmium, copper, chromium, ferum, lead, nickel, aluminium and selenium were analysed by using Inductively Coupled Plasma-Mass Spectrometer (ICP-MS), Agilent 7900, United States.

\section{Results and discussion}

This section discussed concentrations and percentage removal of selected parameters at influent, effluent before and after maintenance service.

\subsection{Concentrations of selected parameter at influent, effluent before and after maintenance service}

Fig. 1 shows the $\mathrm{pH}$ value and concentrations of turbidity, chlorine, nitrate, arsenic, barium, cadmium, copper, chromium, ferum, lead, nickel, aluminium and selenium at influent, effluent before maintenance service and after maintenance service. Whereas, Table 1 shows the allowable limit in National Water Quality Standards [12]. $\mathrm{pH}$ value and concentration of all parameters obtained from the three housing areas were below limit stated in the National Drinking Water Quality Standards except for residual chlorine. pH value was increased from 5.93 to 6.9 after through the water filter before maintenance service. After maintenance service, the $\mathrm{pH}$ was increased higher, from 5.93 to 7.75 which makes water more alkaline.

The turbidity at the influent was much lower compare to the standard, i.e., $0.792 \mathrm{NTU}$ which almost similar to [10] that obtain average turbidity for tap water was 0.86 NTU. This concentration complies with the recommended value of 1 NTU for safe drinking water using chlorine as disinfectants [10]. After passing through the water filter, concentration at the effluent was reduced to 0.433 NTU for before maintenance service. After maintenance service, the turbidity was reduced to $0.263 \mathrm{NTU}$, which clearer water was obtained due to neo sense filter services that help removes the fine particles or dust and other impurities in the water [11]. In addition, the presence of reverse osmosis (RO) membrane with 0.001 micron further reduced the contaminant.

Concentrations of residual chlorine at the effluent of water filter were much lower than the standard. However, these low concentrations may not bring adverse impact to user of the water filter system. The residual chlorine acts as a protection against additional microbial contamination [13]. The water filter system used in this study was designed for user drinking directly at the effluent outlet, which can be classified as indoor water filter system. Thus, additional microbial contamination may not occur. If the water filter system is used outdoor, then the system will not be suitable for contamination can easily occur. For 
any house in Malaysia, water from the mains is channelled into two parts, first directly to the kitchen sink and second is to an elevated water storage tank [14]. If the effluent water is directed to the elevated water storage tank and stored for a long time, the effluent may not safe for drinking due to probability of contamination. In addition, $\mathrm{pH}$ measured after maintenance with value 7.75 which higher than requirement for effective disinfection with chlorine [10]. Thus, residual chlorine was less significant in the water filter system in terms against protection of additional microbial contamination.

Concentration of nitrate was much lower at influent, $0.03 \mathrm{mg} / \mathrm{L}$, compared to the standard. Concentration was reduced at the effluent before and after maintenance from $0.013 \mathrm{mg} / \mathrm{L}$ and $0.005 \mathrm{mg} /$ Lrespectively due to reverse osmosis membrane that had physically separate impurities from the water, including nitrates [11]. For heavy metals, concentrations at influent were much lower compared to the standard, which in range 0.407 $\mathrm{ppb}$ to $75.82 \mathrm{ppb}$. Concentrations at the effluent were reduced in range $0.0121 \mathrm{ppb}$ to 3.397 $\mathrm{ppb}$ for before maintenance service. After maintenance service, concentrations of heavy metals were much reduced in range $0.009 \mathrm{ppb}$ to $0.598 \mathrm{ppb}$ except for aluminium. Concentration of aluminium was increased from $3.397 \mathrm{ppb}$ for before maintenance service to $5.464 \mathrm{ppb}$ for after maintenance service.

$\mathrm{pH}$ value and concentration of all parameters for unfiltered water samples were below the limit stated in National Drinking Water Quality Standards. Thus, this finding shows that without water filter system, the water is safe for drinking. The water filter system was more reduced the contaminants concentrations and increased the quality of water.

Table 1. Allowable limit in National Drinking Water Quality Standards [12]

\begin{tabular}{|c|c|c|c|c|c|c|c|c|c|c|c|c|c|c|}
\hline Parameters & $\mathrm{pH}$ & Turbidity & $\begin{array}{c}\text { Residual } \\
\text { chlorine }\end{array}$ & Nitrate & $\mathrm{As}$ & $\mathrm{Ba}$ & $\mathrm{Cd}$ & $\mathrm{Cu}$ & $\mathrm{Cr}$ & $\mathrm{Fe}$ & $\mathrm{Pb}$ & $\mathrm{Ni}$ & $\mathrm{Al}$ & $\mathrm{Se}$ \\
\hline Unit & & $\mathrm{NTU}$ & \multicolumn{2}{|c|}{$\mathrm{mg} / \mathrm{L}$} & \multicolumn{1}{|c|}{$\mathrm{ppb}$} \\
\hline $\begin{array}{c}\text { Standards } \\
{[12]}\end{array}$ & $\begin{array}{c}6.5- \\
9.0\end{array}$ & 5 & $0.2-0.5$ & 10 & 10 & 700 & 3 & 1000 & 50 & 300 & 10 & 20 & 200 & 10 \\
\hline
\end{tabular}

As: Arsenic; Ba: Barium; Cd: Cadmium; Cu: Copper; Cr: Chromium; Fe: Iron: Pb: Lead: Ni: Nickel; $\mathrm{Al}$ : Aluminium; Se: Selenium

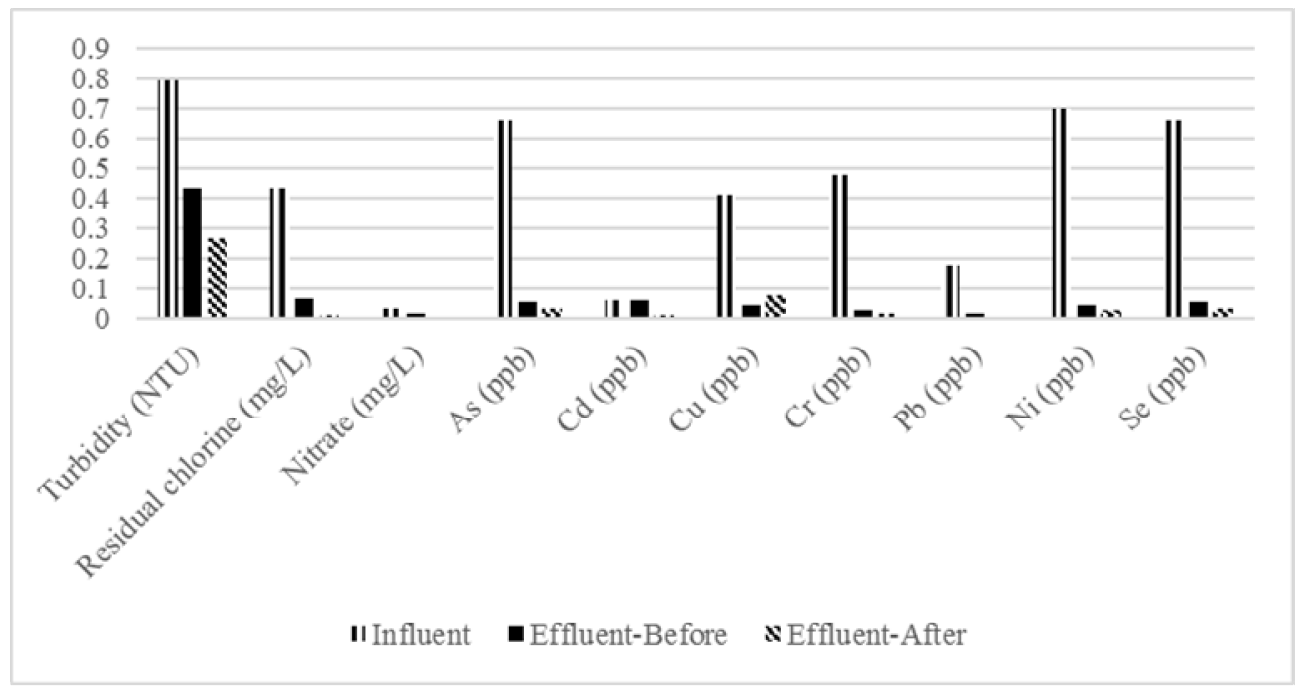

(a) 


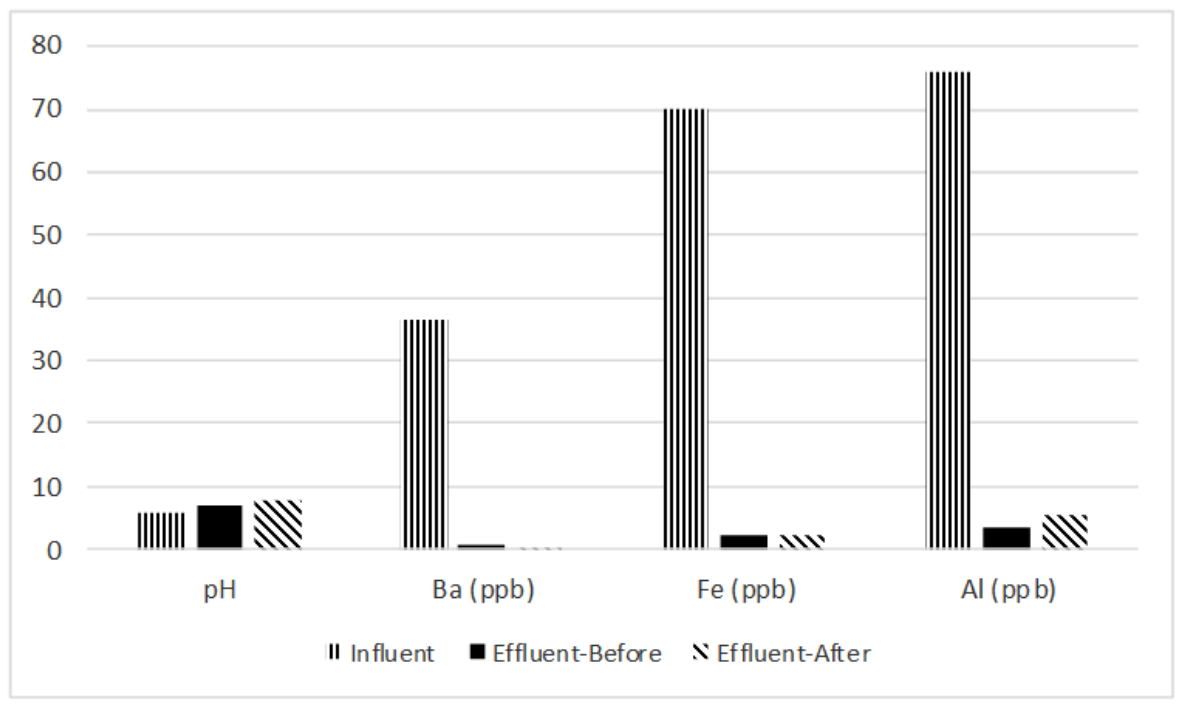

(b)

Fig. 1. Concentrations of $\mathrm{pH}$, turbidity, chlorine, nitrate and heavy metals at influent, effluent before maintenance service and effluent after maintenance service ( $\mathrm{a} \& \mathrm{~b})$.

\subsection{Percentage of Removal of selected parameter before and after maintenance service}

Fig. 2 shows the percentage of removal for before and after maintenance service of $\mathrm{pH}$, turbidity, chlorine, nitrate, arsenic, barium, cadmium, copper, chromium, ferum, lead, nickel, aluminium and selenium before and after maintenance. The increase in pollutant removal shows that sanitation during maintenance service has enhanced the performance of water filter system except for aluminium. Nitrate shows the highest increment, 26.7 and Ferum shows the lowest increment, 0.4.

The sanitation work significantly to enhance the performance of water filter for $\mathrm{pH}$, turbidity, residual chlorine and nitrate. There are three maintenance service provided by manufacturer, namely, sanitation, check-up and filter change [15]. In this study, sanitation was selected due to highest frequency of this service. There are six filters in the water filter system, namely, plus sediment filter, pre-carbon filter, RO membrane, post-carbon filter, fine filter and ceramic filter [11]. During sanitation, only plus sediment filter was backwashed with tap water. Other filter are changed within six months or a year after use following the schedule by manufacturer [15]. The plus sediment filter was use to remove sand, mud and rust [11]. Thus, this removal enhanced the performance of the water filter system to remove turbidity, residual chlorine and nitrate. In addition, $\mathrm{pH}$ also increase due to reduction of impurities during sanitation.

However, the sanitation has reduced the potential of aluminium removal. This may be due to tap water contains high concentrations of aluminium, $75.82 \mathrm{ppb}$ as shown in Table 1 . Thus, aluminium from tap water may flow into the water filter system and reduce the performance after maintenance service. In addition, the sanitation has less significant for removal of heavy metals. For heavy metals, changing of RO membrane may be more significant to the heavy metals removal. RO membrane was used to reduce heavy metals such as arsenic, barium, cadmium, selenium, radium, chromium and lead [11]

A study conducted in 2007 shows that better water quality was obtained for unfiltered water compared to filtered water [2] which contrast to this study. This is may be due to the 
filter not being serviced at all for that year. In 2007, clients are expected to conduct the maintenance service by themselves. By comparison nowadays, many suppliers of water filter system are providing the maintenance service in their package.

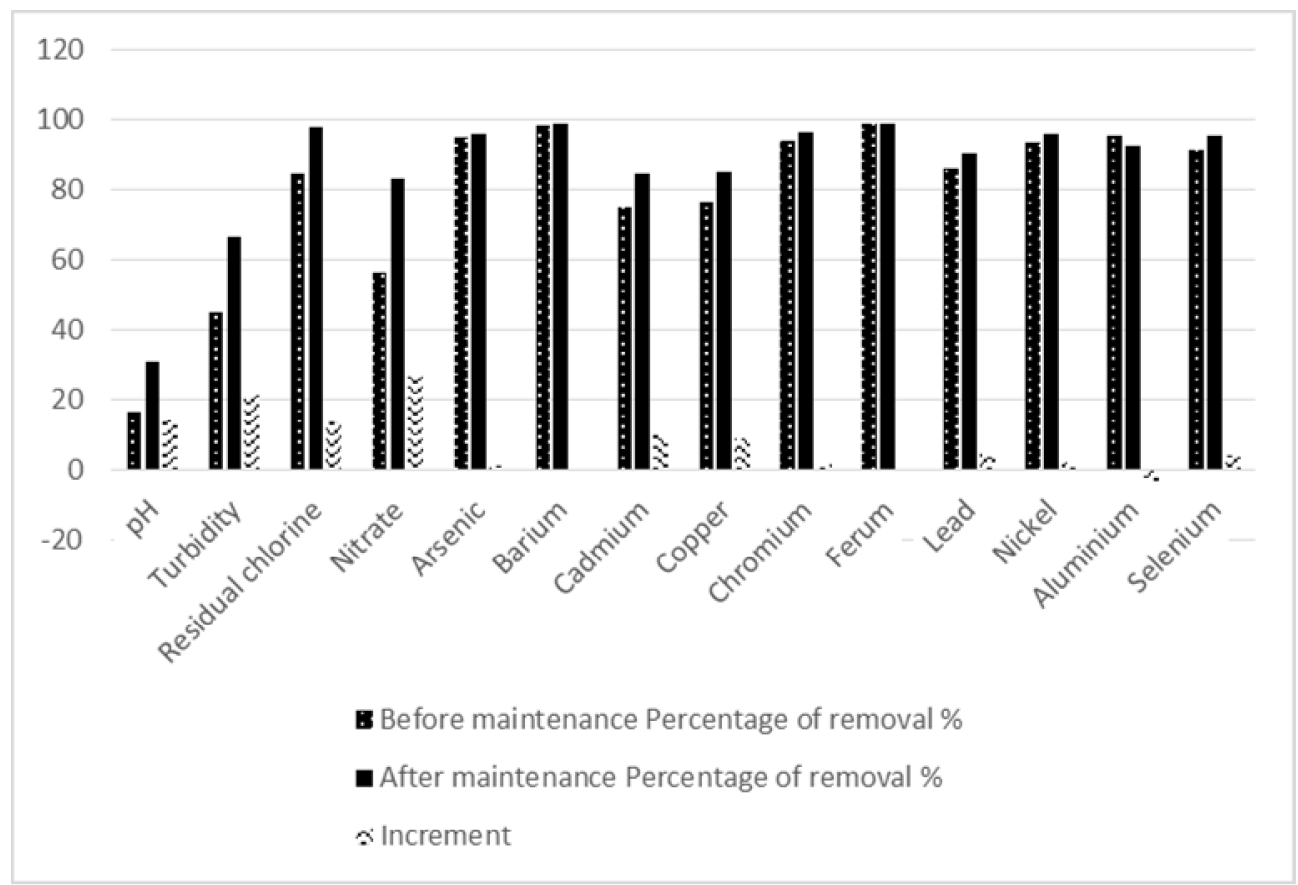

Fig. 2. Percentage of removal for before and after maintenance of $\mathrm{pH}$, turbidity, chlorine, nitrate and heavy metals

\section{Conclusion}

As conclusion, concentrations for all parameters were below the standard which render the water is safe for drinking except for residual chlorine. However, the concentration of residual chlorine may bring adverse impact to user if directly use without storing the water first. All parameters show better removal after maintenance service except for aluminium. The maintenance service enhanced the performance of water filter system for $\mathrm{pH}$, turbidity, residual chlorine and nitrate, but less significance for heavy metals. Thus, the maintenance service, namely, sanitation is required to maintain and enhance the performance of water filter system. It is recommended to measure the effectiveness for emerging pollutants found in pharmaceutical, pesticides, surfactants, industrial additives and solvents. In addition, it was suggested to measure the requirement of maintenance service for outdoor water filter system.

The author would like to thank the supplier of water filter system that had agree to conduct this study. Author also would like to thank for staff of maintenance service for maintenance information. 


\section{References}

[1] K. H. Loh, H. Yaacob, H. Andan, S. Omar and M. Jamaludin, A Study of The Effect of Home Water Filtration Systems On Fluoride Content of Drinking Water in Johor, Malaysian Dental J., 33(2), 8-13, (2011)

[2] R. Mat-Salleh, Water Quality, Perception And Consumer's Satisfaction Towards Domestic Water Filters, Doctoral dissertation, Universiti Putra Malaysia, (2007)

[3] Aini, M. S., Fakhrul-Razi, A., Mumtazah, O., and Chen, J. M. (2007). Malaysian households' drinking water practices: A case study. The Int.l J. of Sustainable Development \& World Ecology, 14(5), 503-510.

[4] F. D. Daschner, H. Rüden, R. Simon, and J. Clotten. Microbiological contamination of drinking water in a commercial household water filter system. European J. of Clinical Microbiology and Infectious Diseases, 15(3), 233-237. (1996)

[5] K. Sadeddin, A. Naser, and A. Firas, Removal of turbidity and suspended solids by electro-coagulation to improve feed water quality of reverse osmosis plant. Desalination, 268(1), 204-207. (2011).

[6] M. Maeng, J. Park, H. Lee, J. E. Tobiason, and S. Dockko. Sustainable technology of trickling biosand filter (TBSF) combined with rock media to reduce organic matters for drinking water. Desalination and Water Treatment, 57(17), 7733-7741. (2016)

[7] B. L. Gulson, A. Sheehan, A. M. Giblin, M. Chiaradia, and B. Conradt. The efficiency of removal of lead and other elements from domestic drinking waters using a benchtop water filter system. Science of the total environment, 196(3), 205-216. (1997)

[8] M. Shafiquzzaman, M. S. Azam, J. Nakajima, and Q. H. Bari. Investigation of arsenic removal performance by a simple iron removal ceramic filter in rural households of Bangladesh. Desalination, 265(1), 60-66. (2011)

[9] R. Devi, E. Alemayehu, V. Singh, A. Kumar, and E. Mengistie. Removal of fluoride, arsenic and coliform bacteria by modified homemade filter media from drinking water. Bioresource technology, 99(7), 2269-2274. (2008)

[10] Ong, C., Ibrahim, S., and Sen Gupta, B. (2007). A survey of tap water quality in Kuala Lumpur. Urban Water J, 4(1), 29-41.

[11]C. S. Yen. U.S. Patent No. 5,914,037. Washington, DC: U.S. Patent and Trademark Office. (1999).

[12] Engineered Services Division Ministry of Health Malaysia. National Drinking Water Quality Standard. (2004)

[13]P. Payment. Poor efficacy of residual chlorine disinfectant in drinking water to inactivate waterborne pathogens in distribution systems. Canadian J. of Microbiology, 45(8), 709-715. (1999)

[14]M. Shuhada. Elak Guna Penapis Air, Harian Metro. 6 Mei 2011.

[15] Interview with staff of maintenance service from water filter system company. (2015) 